\title{
MORE ON DEMOCRATIC FUNDAMENTALS IN SOLOMON ISLANDS: MINISTER FOR PROVINCIAL GOVERNMENT V GUADALCANAL PROVINCIAL ASSEMBLY
}

\author{
Kenneth Brown ${ }^{*}$ and Jennifer Corrin Care
}

In 1997 the High Court of Solomon Islands delivered its decision in Guadalcanal Provincial Assembly v The Speaker of National Parliament, ${ }^{1}$ declaring void the Provincial Government Act $1996,{ }^{2}$ on the basis that several parts of that measure were unconstitutional. That decision was considered ${ }^{3}$ and criticised ${ }^{4}$ in an earlier article.

The Court of Appeal allowed an appeal against that judgment. This paper examines the Court of Appeal's decision and comments on its significance for Solomon Islands and the South Pacific region

* Kenneth Brown is a former magistrate and Public Solicitor of Solomon Islands and is presently a PhD candidate at Northern Territory University, Australia, researching customary law in Solomon Islands and Vanuatu.

** Jennifer Corrin Care is a Senior Lecturer in law at the University of Queensland and a Barrister and Solicitor of Fiji and Solomon Islands.

1 Guadalcanal Provincial Assembly $v$ The Speaker of National Parliament (26 February 1997) unreported, High Court, Solomon Islands, Civ Cas 309/9.

2 Provincial Government Act 1996, no 3 of 1996.

3 The first instance decision in this case was discussed in Corrin Care, J "Democratic Fundamentals in the Solomon Islands" (1997) 27 VUWLR 501.

4 Corrin Care, above n 3, 511. 
generally. In particular, it considers the extent of state legislative power, the role of a preamble, and the human rights implications for women.

\section{CASE HISTORY}

\section{A The Decision at First Instance}

In early 1996 Parliament passed the Provincial Government Act. This purported to repeal the Provincial Government Act 1981 and replace the existing system of provincial government with a new regime. In place of the offices and bodies established under the 1981 Act, provision was made for ten Area Assemblies within each province. These were to be constituted half by elected members and half by appointed chiefs and elders. Each province was also to have a Provincial Council, instead of the existing Provincial Assembly. This Council was to be constituted by the Chairs of all the Area Assemblies in the province. It was therefore possible for the legislature of a province to consist exclusively or predominantly of non-elected members.

The 1996 Act was challenged in Guadalcanal Provincial Assembly $v$ The Speaker of National Parliament and the Minister for Provincial Government. ${ }^{5}$ Palmer J concluded that the establishment of, and conferring of functions on, Provincial Councils under Part III and IV of the 1996 Act was unconstitutional. He considered the lack of provision for accountability by an elected assembly to contravene the principles of representative and responsible government. He viewed democratic accountability to be an integral part of the fabric of the written Constitution of Solomon Islands.

He went on to hold that the establishment of, and conferring of functions on, the Area Assemblies under Part V and VI of the 1996 Act was also inconsistent with the underlying constitutional principles of representative and responsible government. In addition to the lack of accountability, it did not constitute a truly representative form of government, as nonelected members might be in a position to control the Chair and the "mind" of the Assembly. He condemned this as particularly objectionable in the light of the fact that the Assembly had both executive and legislative authority.

5 Guadalcanal Provincial Assembly $v$ The Speaker of National Parliament and the Minister for Provincial Government (26 February 1997) unreported, High Court, Solomon Islands, Civ Cas 309/96. 
Palmer J also considered Parliament's legislative power to legislate for provincial government, conferred by section 114 (2) of the Constitution. Much turns on the pithy wording of this section, which reads: 6

Parliament shall by law-

(b) make provision for the government of Honiara city and the provinces and consider the role of traditional chiefs in the provinces.

His Lordship held that the exercise of the power granted by section 114(2) so as to provide for the possibility of elevation of chiefs (or elders) ${ }^{7}$ to key and/or controlling positions in provincial government was contrary to the democratic notions of representative and responsible government enshrined in the broad tenor of the Constitution.

Accordingly, Palmer J declared Parts III, IV, V, VI of the 1996 Act void. As, in His Lordship's view, the principles outlined could not be separated or severed without wholesale amendment of the Constitution, commencing with the preamble, the whole Act was void.

\section{B The Decision on Appeal}

In 1997, the Court of Appeal in The Minister for Provincial Government $v$ Guadalcanal Provincial Assembly, ${ }^{8}$ heard an appeal from Palmer J's decision. The main issues for consideration, as at first instance, were:

- whether the Constitution required the system of government, including provincial government, to comply with principles of representative and responsible government; and if so

- whether the 1996 Act contravened those principles.

Kapi P referred to the English common law approach of allowing the preamble to be used in interpreting sections of a statute only in cases of ambiguity. ${ }^{9}$ He reviewed the case law

6 The section was inserted to pacify secessionist sentiments in the lead-up to independence.

7 Section 114(2) refers to "chiefs" only, but the 1996 Act referred to "chiefs and elders". At first instance, Palmer J suggested that Parliament was bound by "the express and specific words of the Constitution" and was not allowed to provide for the role of "elders" in provincial government.

8 The Minister for Provincial Government v Guadalcanal Provincial Assembly (11 July 1997) unreported, Court of Appeal, Solomon Islands, Civ App 3/1997. 
from other jurisdictions and determined that the preamble was an unqualified part of the text of a constitution and could be used in interpretation of other provisions, whether or not there was ambiguity. He concluded by observing:

I consider that the preamble of the Constitution of Solomon Islands is no different to the nature of preambles in other constitutions. The preamble is a general statement of jurisprudential philosophy or underlying principles or beliefs by the people as the basis of the new nation. To this extent it is permissible as has been illustrated by decisions from other jurisdiction for courts to have regard to preambles in construing provisions of Constitutions. However, in my opinion, these general statements must not be read as constituting legal principles on their own.

As pointed out by Kapi $\mathrm{P}$, in order for the preamble to be of use, there had to be some applicable provisions to interpret. He felt that section 114 of the Constitution left the nature and powers of provincial government entirely to the National Parliament and that nothing in the Constitution dealing with executive government or the national legislature (Chapters $\mathrm{V}$ and VI) required Parliament to comply with democratic principles when legislating for provincial government.

The only remaining question was whether such provisions could be implied. Kapi P had no doubt they could not. Williams JA believed that the judge at first instance had, in essence, resolved the issue by consideration of express provisions of the Constitution. Accordingly he felt that this was "not an appropriate case in which to finally determine the Court's power with regard to implying terms into the Constitution or drawing implications therefrom. "10 In any event, Williams JA was of the view that there was nothing undemocratic in the provisions of the 1996 legislation. Goldsborough JA concurred in the view that this was not a proper case in which to consider whether a necessary implication arose, but based his decision on the fact that the necessary implication of democratic principles into the Constitution had not been argued by counsel for the respondent and neither had the counsel for the appellant had the opportunity to argue the point in response. The appeal was therefore allowed and the 1996 Act confirmed as valid.

9 Attorney-General v Prince Ernest Augustus of Hanover [1957] AC 438. Williams JA, 22, distinguished this case on the grounds that it concerned the position when the statute under construction was clearly divided into a preamble and an enacting part.

10 Attorney-General v Prince Ernst Augustus of Hanover, above n 9, 28. 


\section{COMMENTARY}

\section{A The Preamble}

Traditionally, a preamble is a section at the beginning of a statute, which sets out why the legislation is necessary. This can be contrasted with the long title, which states the main legal changes the Act is to make to fill that need. Typically, the preamble contains a recital of the mischief which the Act is designed to remedy. Preambles are often identifiable by the opening word "Whereas". They are rarely used today, except in documents of international significance, such as legislation implementing multilateral treaties and legislation of constitutional importance. They may also be found in legislation of an historic nature and legislation dealing with personal or private interests. In many constitutions of the Pacific region an introductory section has been used to incorporate expressions of the values and ideals said to underpin the constitution. This is the case with the Solomon Islands Constitution. The question arises whether this is properly called a "preamble" or is really something rather different, which ought to be separately categorised.

The term "preamble" is not found in the Solomon Islands Constitution itself, although it is used as a heading to similar clauses in other regional constitutions, for example, the Constitution of Tuvalu. However, a distinction may be drawn between the Solomon Islands Constitution and that of Tuvalu, where the preamble is combined with the enacting words. In the Solomon Islands Constitution, the paragraphs containing underlying principles and philosophies are separate and use the words "declare" and "agree and pledge" in capital letters. Accordingly, they might perhaps be more correctly referred to as the "Declaration, Agreement and Pledge".

The counter-argument, that this introductory part was intended as a preamble, even though it does not commence with the traditional words or deal with the traditional subjectmatter, gains support from the Report of the Solomon Islands Constitutional Conference. ${ }^{11}$ The Conference met in 1977 to consider the Chapters of a Position Paper adopted by the Solomon Islands Legislative Assembly. The Conference agreed that the Constitution should embody the principles set out in the Report, including the following paragraph:

Preamble

11 Report of the Solomon Islands Constitutional Conference (Miscellaneous Paper No 22, London, 1977). 
(a) all power in the country belongs to the people of Solomon Islands, and is exercised on their behalf by the legislature, executive and the judiciary established by the Constitution;

(b) $\ldots$

(c) $\ldots$

(d) the system of government is based on democratic principles of universal suffrage and the responsibility of executive authorities to elected assemblies;

(e) a commitment to decentralisation of legislative and executive power ...

Perhaps the most important consideration is whether the reasoning within the judgments dealing with traditional preambles may properly be applied to the commencing words of the Constitution, whatever they are labelled.

The status of the "Declaration, Agreement and Pledge" or "preamble" was of considerable significance in the Court of Appeal's judgment. As already noted Kapi P cited the English common law tradition of refusing to use the preamble as a guide to statutory interpretation except in clear cases of ambiguity. However, his wide-ranging survey of Commonwealth case law led him to conclude that the preamble was an unqualified part of the text of a constitution and could be used in interpretation of other provisions even in the absence of ambiguity.

However, his Lordship declined to employ the "preamble" as an aid to interpretation in this case, as he viewed the legislative power set out in section 114 in relation to provincial government as unequivocal. The preamble could not itself be used as a directive to this effect and, as there was no discernible directive in the Constitution requiring Parliament to exercise its powers in a particular way, it could not be used to demand compliance with democratic principles when legislating for provincial government.

Goldsborough JA agreed that the preamble could not be used as a substantive provision and took the traditional line regarding its use as an aid to interpretation. Whilst recognising that the word "preamble" did not appear in the Constitution and emphasising that the title was used only "for the sake of convenience", his Lordship expressed the view that later provisions must stand alone except where their meaning was ambiguous.

Williams JA also made it clear that he used the term "preamble" only for the sake of convenience. He took a different approach on its effect, drawing a distinction between a statute which is clearly divided into a preamble and an enacting part and one, such as the Solomon Islands Constitution, where the introductory words are "as much a part of the 
Constitution as any of those clauses." Accordingly, he considered that Attorney-General $v$ Prince Ernest of Hanover ${ }^{12}$ had no application, being an authority for the approach to be adopted only when construing a statute clearly divided into a preamble and an enacting part.

The Irish Constitution commences with a declaration, including the aspiration of "seeking to promote the common good, with due observance of Prudence, Justice and Charity, so that the dignity and freedom of the individual might be assured". This has been used as the basis for judicial activism in a number of Irish cases. For example, in McGee v Attorney General Walsh J said: ${ }^{13}$

According to the preamble, the people gave themselves the Constitution to promote the common good with due observance of prudence, justice and charity so that the dignity and freedom of the individual might be assured. The judges must, therefore, as best they can from their training and their experience interpret these rights in accordance with their ideas of prudence, justice and charity. It is but natural that from time to time the prevailing ideas of these virtues may be conditioned by the passage of time; no interpretation of the constitution is intended to be final for all time.

If English precedent applying to preambles was distinguishable on the basis that it applied only to traditional preambles, which served a different purpose to the declaration in the Solomon Islands, it followed that the weight and use of the introductory words was an open question. In particular, there was nothing prohibiting their use as substantive provisions, and so providing the directive that Kapi $\mathrm{P}$ found missing. It is unclear whether Willams JA would have been prepared to go this far; his finding that the provisions of the 1996 Act were not undemocratic made it unnecessary for him to make this decision.

\section{B Traditional chiefs, discrimination and customary law}

The crucial legal issue in contention ostensibly revolved around the interpretation of the "preamble" to the Constitution and its effect in relation to the powers of the legislature. Preoccupation with this question clouded a significant rights issue. Discrimination appeared as a side issue only on appeal. The critical area was the position of traditional leaders.

The Court of Appeal considered briefly whether the 1996 Act was discriminatory without, it would appear, hearing argument on point. It determined it was not. This view that

12 Attorney-General v Prince Ernest of Hanover [1957] AC 436.

13 McGee v Attorney-General [1974] IR 284. See also The State (Healy) v Donoghue [1976] IR 325. 
discriminatory provisions are validated by Parliament's mandate to consider the role of traditional chiefs in provincial government fails to consider the legislative power in the context of the fundamental rights provisions.

The Constitution requires section 114 to be exercised within the boundaries of the rights agenda. The relationship of the non-discrimination charter to customary law is crucial but has not yet been sufficiently argued. To understand the dilemma some key measures of the Constitution require comment. The starting point is sections 75 and 76 .

These stipulate:

75 (1) Parliament shall make provision for the application of laws, including customary laws.

(2) In making provision under this section, Parliament shall have particular regard to the customs, values and aspirations of the people of Solomon Islands.

76 Until Parliament makes other provision under the preceding section, the provisions of Schedule 3 to this Constitution shall have effect for the purpose of determining the operation in Solomon Islands-

(a) of certain Acts of the Parliament of the United Kingdom mentioned therein;

(b) of the principles and rules of the common law and equity;

(c) of customary law; and

(d) of the legal doctrine of judicial precedent

Section 76 is an essential corollary to section 75. It is a non-substantive sweeping-up provision directing reference to Schedule $3^{14}$ for the application and precedence of laws until

14 "Application of Laws

1 Subject to this Constitution and to any Act of Parliament, the Acts of the Parliament of the United Kingdom of general application and in force on 1st January 1961 shall have effect as part of the law of Solomon Islands, with such changes to names, titles, offices, persons and institutions, and as to such other formal and non-substantive matters, as may be necessary to facilitate their application to the circumstances of Solomon Islands from time to time.

2 (1) Subject to this paragraph, the principles and rules of the common law and equity shall have effect as part of the law of Solomon Islands, save in so far as:

(a) they are inconsistent with this Constitution or any Act of Parliament; 
Parliament makes specific legislative provision. This is essential in view of the inaction of Parliament. ${ }^{15}$ The section contemplates that it is to be a transitional and temporary measure but the probability is that it is likely to remain as a long-term, if not permanent feature.

Sections 75 and 76, as examined with Schedule 3, are prescriptive and brand customary law as substantive and organic. Paragraph 3(3) of Schedule 3 in no way limits this, catering only for programmatic non-substantive matters.

The Solomon Islands Constitution Chapter II is headed Protection of fundamental rights and freedoms of the individual. This chapter's origins lie in Western declarations and it follows the widely-used formula in British designed constitutions of defining and granting the right or freedom and then immediately proceeding to limit the scope of its exercise and operation. This is conspicuous from section 15, the measure having direct relevance to discrimination and customary issues.

(b) they are inapplicable to or inappropriate in the circumstances of Solomon Islands from time to time; or

(c) in their application to any particular matter they are inconsistent with customary law applying in respect of that matter.

(2) The principles and rules of the common law and equity shall so have effect notwithstanding any revision of them by any Act of the Parliament of the United Kingdom which does not have effect as part of the law of Solomon Islands.

3 (1) Subject to this paragraph, customary law shall have effect as part of the law of Solomon Islands.

(2) The preceding subparagraph shall not apply in respect of any customary law that is, and to the extent that it is, inconsistent with this Constitution or an Act of Parliament.

(3) An Act of Parliament may:

(a) provide for the proof and pleading of customary law for any purpose;

(b) regulate the manner in which or the purposes for which customary law may be recognised; and

(c) provide for the resolution of conflicts of customary law."

15 An added imperative of the section is the obvious problem of legislating for all conceivable situations. 
Section $15^{16}$ is a fairly standard non-discrimination clause. Although modern human rights norms are premised in Western juristic values it is often claimed that they represent universal values and thus are culturally neutral. ${ }^{17}$ The arena and exposition of human rights is founded on the expression of guiding civilised behavioural norms. Human rights are, like Western law systems, rule dominated. It is doubtful if traditional Pacific island societies had a rule orientated culture.

Non-discrimination is critical in the divide between Western values and the needs of custom. This is so because patriarchal values are, at least formally, overriding and ubiquitous

16 "15 (1) Subject to the provisions of subsections (5), (6) and (9) of this section, no law shall make any provision that is discriminatory either of itself or in its effect.

(2) Subject to the provisions of subsections (7), (8) and (9) of this section, no persons shall be treated in a discriminatory manner by any person acting by virtue of any written law or in the performance of the functions of any public office or any public authority.

(3) Subject to the provisions of subsection (9) of this section no person shall be treated in a discriminatory manner in respect of access to shops, hotels, lodging houses, public restaurants, eating-houses or places of public entertainment or in respect of access to places of public resort maintained wholly or partly out of public funds or dedicated to the use of the general public.

(4) In this section, the expression "discriminatory" means affording different treatment to different persons attributable wholly or mainly to their respective descriptions by race, place of origin, political opinions, colour, creed or sex whereby persons of one such description are subjected to disabilities or restrictions to which persons of another such description are not made subject or are accorded privileges or advantages which are not accorded to persons of another such description.

(5) Subsection (1) of this section shall not apply to any law so far as that law makes provision-

(d) for the application of customary law.

17 See the analysis in Bennett Human Rights and African Customary Law (Juta \& Co, Cape Town, 1995) 2-5. This work, ostensibly concerned with the South African Interim Constitution of 1993, is a lucid general exposition and examines all the crucial issues. R Pannikar "Is the Notion of Human Rights a Western Concept?" (1982) 120 Diogenes 75 answers his own question in the affirmative. His argument shows that the roots of modern human rights are Western, liberal and protestant and that a cultural value only exists in a given cultural context. For an incisive and valuable contribution on Asia see Yash Ghai "Human Rights and Asian Values" (1998) 9 Public Law Review 168. 
in customary societies. ${ }^{18}$ This patriarchy pervades not only the social norms but also the command and control of institutions. ${ }^{19}$

Non-discrimination prescriptions outlaw much of this patriarchal edifice and some newly independent nations have chosen to protect customary norms by exempting customary matters from the body of fundamental rights. The rationale for this course is twofold: a desire to preserve traditional structures to enhance "harmony" and social stability ${ }^{20}$ and a recognition that cultural constructs cannot be eradicated overnight by high-sounding declarations. They superficially display an allegiance to what might be termed the idealised golden age view of customary law.

The disciples of this theory view custom as a benign agent in promoting social harmony. The belief that custom has slowly matured into an inherently worthy assemblage of norms embodying distilled and tested wisdom may in fact be wishful thinking. ${ }^{21}$ At its heart it is a conservative manifesto. Therefore it serves the interests of those with most to lose from any social transformation. Those who defend the existing social order are likely to be senior men.

Custom for many may be a means of retaining social and, by extension, political control; "harmony" being employed merely as a pleasant-sounding, acceptable euphemism. It is important to be aware that those who promote a forceful custom agenda may be fighting to retain social authority and power.

18 As indeed they were in the West until the rise of feminism in the second half of the 20th century.

19 For a comprehensive review of the power and influence of patriarchal norms in Melanesia see DD Johnson, "Aspects on the Legal Status of Women in Papua New Guinea" (1979) 7 Melanesian Law Journal 5. For an analysis of how the courts of Papua New Guinea have tackled the patriarchal bedrock of customary practice see Jessep O "Village Courts in Papua New Guinea: Constitutional and Gender Issues" (1992) 6 Int Journal of Family Law 401. The saga continues there: see the case of In re Kepo Raramu and the Yowe Village Court (1994) PNGLR 486 where a judge condemned as unconstitutional the actions of a village court which had imprisoned a widow for breaching custom by going around with other men.

20 As Bennett, above $\mathrm{n} 17,5$ indicates age, tradition and the past are venerated in customary societies. In contrast the West venerates and worships youth, vitality, "the new" and glamour.

21 See the exposition in Chanock M Law Custom and Social Order, (Cambridge University Press, New York, 1985) 4 and following, dispelling the "continuity" theory. He argues convincingly that there is a large element of myth making in the construction of customary law. 
Section 15(5)(d) of the Solomon Islands Constitution enables Parliament when providing for the application of customary law, to do so in a manner that may be discriminatory. ${ }^{22}$ This protecting of customary law from the usual application of the norms of equality is a highly contentious issue.

The political position of women is precarious if they are exposed to the full rigours of customary law. ${ }^{23}$ In marriage and landholding their legal rights are fragile and their formal social status low. Their political leverage is negligible. That there remains a long road to actual equality is exemplified by the rationale behind some comment in the case under review.

The prescription of the 1996 Act replaced a system of Provincial Assemblies made up entirely of elected members with a non-democratic model based on Provincial Councils to which members were indirectly elected by Area Assemblies. These Area Assemblies consisted of equal numbers of elected members and members appointed from chiefs and elders. Williams JA surveyed the Act and the Constitution and concluded:

Firstly the traditional position is that only a male can be a "traditional chief". That means that onehalf of the members of the Area Assembly must be males and that, it might be said, effectively denies females equal opportunity with males. There is certainly force in this argument, but the answer in essence is that the Constitution recognises that the "traditional chiefs" should play a role in government at the provincial level. The Constitution itself therefore recognises this imbalance or discrimination and it will remain until the role of "traditional chiefs" under the Constitution is reevaluated. Initially the role of women in government will be limited to standing for election to Area Assemblies, and undoubtedly when that has become more readily accepted, consideration will be given to the discriminatory effect of appointing chiefs and elders pursuant to sections 30 and 31 of the 1996 Act.

22 Solomon Islands is not a party to the 1979 United Nations Convention on the Elimination of All Forms of Discrimination against Women (CEDAW) United Nations. If it were, the protective fence around customary law would have to be dismantled.

23 The authors examine the present state of affairs in "Conflict in Melanesia: Customary law and the Rights of Women" (1999) 24 (3\&4) CLB 1334. The article does not touch on Papua New Guinea, the largest Melanesian population base but the situation there is neatly summed up by Los J in State $v$ Kopilyo Kipungi and Others (1983) N 437: "Although the equality of the sexes is now a constitutional principle in Papua New Guinea, at this stage it is more a matter of books, rather than practice. The character of all aspects of life is a male dominance." 
Goldsbrough J A echoed this analysis and commented:

Parliament has made provision for provincial government. It was required to do so. It has considered, as required, the role of traditional chiefs. Indeed it has decided to enhance their role as compared to the repealed legislation. In this regard it is clear that women may be disadvantaged, given that traditional chiefs are male. This I conclude cannot be said to offend against the Constitution, as it is a required consideration by that same constitution.

These passages acknowledge that genuine equality is at the gift of men, as realistically they will dominate any body that re-evaluates the role of traditional chiefs. The political power base of men in provincial government will therefore remain unaltered unless men themselves determine otherwise.

The assertion that as the Constitution dictates that Parliament must consider the role of traditional chiefs the manner in which it did so was of no legal moment is, it is submitted, legally untenable. What the Appeal Justices ${ }^{24}$ seem to be contending is that Parliament was charged by the Constitution to provide for the position of traditional chiefs and that if it devised a formula for doing so that was discriminatory then that discrimination was sanctioned by the Constitution itself. This reasoning is circuitous and faulty. The Constitution does not bestow upon Parliament any power to make laws that are discriminatory in their effect. In fact such laws are specifically outlawed by section 15 (1) of the Constitution declaring in categorical terms: "no law shall make any provision that is discriminatory either of itself or in effect." This and similar injunctions in the Chapter II circumscribe the legislative power. There are exceptions to this; the only possibly pertinent one in this context being section 15(5) (d) relating to a law providing "for the application of customary law." This seems to be a direct reference to the legislative power in section 75(1) to "make provision for the application of laws, including customary laws." The Provincial Government Act cannot be denoted as such a law. ${ }^{25}$

24 Notably Kapi J, the Acting President of the Court who in delivering the leading judgment did not refer or consider the discriminatory aspect of the legislation He preferred to rest his conclusions on the unlimited power of Parliament.

25 Palmer J at first instance had adopted a purposive view of the Constitution and denounced the Act as discriminatory. This is not the only example of a Pacific Court of Appeal embracing a conservative agenda: see Saipa'ia Olomalu and others v Attorney-General [1980-93] WSLR 41 and more recently the Solomon Islands Court in Aseri Harry v Kalena Timber Company Ltd (19 April 2000) unreported, Court of Appeal, Solomon Islands, Civ App 64/1994. 
Section 114(2) empowers Parliament to "consider the role of traditional chiefs ...". This is not a laissez-passer granting any authority to introduce discrimination by the back door. Any consideration Parliament bestows must be within the parameters of the Constitution. The legislative power is not unlimited although some dicta may suggest otherwise. ${ }^{26}$

Can any persuasive argument be put forward that as the 1996 Act seeks to confirm the deference which custom accords to traditional chiefs ${ }^{27}$ it is indirectly and implicitly providing "for the application of customary law" and therefore exempted from the non-discrimination agenda? Or expressed in another way, must a law providing for the application of customary explicitly state that it is so doing?

In clear cases there will be no controversy. The Customs Recognition Act $2000^{28}$ manifestly was intended to make application for customary law and in the objects and reasons laid before Parliament during the passage of the Act, the Minister directly made reference to both section 75 and Schedule 3 of the Constitution. Certain aspects of this $\mathrm{Act}^{29}$ are either expressly or in their probable effect discriminatory against women. To exempt any provision from being regulated by the prescription for non-discrimination unequivocal words, expressly invoking the application of custom, would it is argued be mandatory.

Applying this test to the 1996 Act, the measure can by no yardstick, be providing "for the application of custom". What it does is entrench the power and authority of senior men and reinforce the existing rigid social structure. The use of the appellation "elder" reinforces this. The Appeal Justices in an effort to uphold the legislative power have, it is submitted, erroneously interpreted "consider" far too widely. The wording of section 114(2)(b) of the Constitution cannot be taken to assign to Parliament the authority to make such provision for traditional chiefs as Parliament thinks fit. Expressed somewhat differently, an authority given

26 See below $\mathrm{n} 27$.

27 The 1996 Act sought also to preserve a role for "elders" who are not mentioned in s 114(2). Nevertheless Kapi J ruled that "The Parliament has unlimited power to make provision for such elders in a manner it considers appropriate." It is submitted that this is erroneous; Parliament cannot pass a law that is unconstitutional in itself: Kenilorea $v$ Attorney-General [1984] SILR 179. A feature of Kapi's judgment is that it avoids the issue of the discriminatory effect of the 1996 Act.

28 This Act has yet to be brought into force.

29 For example ss 8 (f) and 9, governing custom and marriage and the custody and guardianship of infants. 
to Parliament to "consider" does not confer a power to legislate in a manner that offends one of the fundamental rights of the Constitution.

Balancing the completing claims of custom and modern norms is a daunting task requiring sensitive treatment by the legislature and judiciary. The examples of the Provincial Government Act 1996 and the Solomon Islands National Provident Fund (Amendment) Act 199030 give little reason for women to expect Parliament to champion their interests. Parliament must walk a fine line when enacting legislation that might impinge on equality for women, as any attempt to prefer or bolster existing male power is open to attack as being unconstitutional. As a corollary to this, the judiciary must be on the alert to identify and strike down existing legislation that is discriminatory.

Social resistance will undoubtedly meet the claim by women for equality. Socially they tread a quicksand of embedded taboos and practices. More optimistically, legally they have section 15(1). To date minute judicial analysis of the scope of this provision has not been forthcoming nor has it been the subject of full argument in a superior court. The use of the word "provision" in the phrase "no law shall make any provision that is discriminatory either of itself or in its effect" might at first be thought to refer to a written law only and thus not proscribe a rule or practice of custom. However this approach fails on two grounds. Firstly if "law" in the subsection is not to be interpreted as including any law from whatever source, thus including customary law, then the power contained in section 15(5)(d) of the Constitution to distinguish customary law from the general equality prescription is redundant. It also seems section 15(1) employs the term "law" in a generic sense. By contrast subsection (2) specifically refers to "any written law" and section 15(5) clearly envisions, by the categories of exemption, the enactment of a written law. This interpretation is crucial for them as it interdicts any rule of custom that is discriminatory and represents a powerful weapon for women.

The composition of political bodies in Solomon Islands presents striking proof that patriarchy flourishes there. Whilst the ideology undermines the standing of women, it may be the Achilles heel of customary law as it is the area in which customary values are vulnerable to attack. Customary law is unlikely to survive, except perhaps as museum piece, if it insists

30 This Act referred the inheritance of contributions to the Local Court of the deceased home area if the member had not nominated to whom his contributions should be paid on his death. In practice this will favour men: see Tanavalu $v$ Tanavalu and Solomon Islands National Provident Fund (12 January 1998) unreported, Court of Appeal, Solomon Islands, Civ App 3/1998. 
on buttressing male power and authority. ${ }^{31}$ Such a route lays customary law open to ridicule and

if those exercising political powers endorse it then aid and trade may be affected. ${ }^{32} \mathrm{~A}$ demonstration of a willingness to work towards the attainment of equality is important and attempts to invoke the protective shield of section 15(5)(d) of the Constitution can only be counterproductive to the long-term prospects for customary law.

\section{Tanavulu and Tanavulu $v$ Tanavulu and SINPF}

The central plank on which the decision in The Minister for Provincial Government $v$ Guadalcanal Provincial Assembly ${ }^{33}$ stood was the Court's reluctance to question or limit the legislative power of Parliament. In Tanavulu and Tanavulu $v$ Tanavulu and $\operatorname{SINPF}^{34}$ a differently constituted court adopted the same conservative line and endorsed the ambit of the legislative power in cases involving custom and issues of possible discrimination. There, the court had to consider customary inheritance for the purpose of the Solomon Islands National Provident Fund Act. ${ }^{35}$ That Act provides that where a member of the Fund dies without nominating a beneficiary for their accumulated funds, distribution is to be in accordance with the custom of the member, "to the children, spouse and other persons" entitled in custom. ${ }^{36}$ No provision is made as to how this custom is established. In this particular case, the deceased had nominated his brother and nephew as beneficiaries when he joined the fund. As provided by section 32 of the Act, that nomination became void when he married the following year. After his son's death, the deceased's father applied for and was paid the amount held in the fund on the basis of custom in Babatana, South Choiseul. Of the $\$ 11,079$ paid to him, the father deposited $\$ 4,000$ in an interest-bearing deposit account in the

31 This argument is developed in K Brown "Customary law in the Pacific: an endangered species?" [1999] 3 JSPL 2.

32 The United Nations, the United States and countries of the European Union all monitor human rights and aid and assistance programmes can be dependent on a good report. Countries that do not promote gender equality may find themselves the subject of increasing pressure from women's groups and organisations.

33 (11 July 1997) unreported, Court of Appeal, Solomon Islands, Civ App 3/1997.

34 (12 January 1998) unreported, High Court, Solomon Islands, Civ Cas 185/1995.

35 Solomon Islands National Provident Fund Act Cap 109.

36 Solomon Islands National Provident Fund Act, s 33(c). 
name of the deceased's son. He used $\$ 3,000$ to meet funeral expenses and paid $\$ 2,000$ each to the deceased's brother and nephew. $\$ 79$ was used for his own purposes. The deceased's widow challenged this distribution, seeking a declaration in the High Court that she and her infant child were entitled to a third share of the money each. The evidence in the case showed that inheritance in the deceased's tribe was patrilineal and that the deceased's father was entitled to distribute the estate to relatives. According to customary law the deceased's father had the discretion to pay some amount of the inheritance to the widow, but in some circumstances, for example, as where she had left the father's house, he was entitled to leave her out of the distribution altogether.

Most of the argument concentrated on the interpretation of section 33(c). However, it was also argued for the widow, at trial, that the customary law as found was discriminatory and hence unconstitutional. The judge found that the word "law" in section 15(1), did not include customary law. His basis for this finding was that the section was referring to a law to be made in the future and customary law was not such a law. Rather it was "evolving or was already pertaining at the time of the adoption of the Constitution". This interpretation puts customary law outside the protection of section 15 for all purposes. However, it is open to serious question. Whilst the word "shall" may generally be used to denote indefinite future time, legislative drafters employ it to denote an obligation. ${ }^{37}$ In a negative phrase such as "no law shall" it means "a law must not ...". His Lordship went on to say that discriminatory customary law would not be outlawed by sub-section (1) in any event, because he considered that section 15(5)(c) and section 15(5)(d) excused discriminatory law in a case such as this.

Section 15(5)(c) exempts law, inter alia, "with respect to devolution of property on death". Arguably this would not cover the distribution of funds under the National Provident Fund Act, as the Act removes entitlements from the Fund from a deceased's estate for testamentary purposes.

It appears that the allegations of discrimination were not pursued before the Court of Appeal. Nor were the arguments expressed above on the meaning of section 15 put forward. The Court of Appeal upheld the first instance decision and limited its consideration of the conflict between customary law and protection from discrimination to the following words:

The Constitution (s 15(5) and $\mathrm{cl} 3$ of Schedule 3) recognises the importance of customary law to citizens of the Solomon Islands. The former provision recognises that the application of customary

37 See further GC Thornton Legislative Drafting (3 ed, Butterworths, London, 1987) 90. 
law may have certain discriminatory consequences. The learned trial judge was correct in holding that the Act was not unconstitutional because section 36(c) discriminated against the widow.

Like the Court of Appeal's ruling in The Minister for Provincial Government $v$ Guadalcanal Provincial Assembly, 38 the practical effect of this decision is to perpetuate discrimination founded on customary law and practice.

\section{CONCLUSION}

Ironically, following the decision in the Provincial Government Case, Parliament enacted the Provincial Government Act 1997, which repealed the Provincial Government Act 1996 and reenacted the Provincial Government Act 1981 with all amendments made prior to its repeal. It also contained modifications and transitional provisions necessary in consequence of the repeal of the 1996 Act and other incidental provisions. Whilst this legislation resolves the problem of undemocratic and discriminatory provisions in this particular case, the potential for conflict between principles of democracy and human rights on the one hand and customary law on the other remains. With regard to the principles of democracy, without specific provision within the Constitution, the Court of Appeal has made it abundantly clear that the courts' hands are tied. To this extent the decision is in keeping with the views expressed in the earlier article, ${ }^{39}$ where it was pointed out that democracy is an abstract concept. It was also stressed that the search for a definition of democracy in Solomon Islands is particularly complex, as democracy is a Western cultural concept.

With regard to human rights, and particularly women's rights, the conflict with customary law highlighted here is part of the wider debate on the relationship between introduced law and customary law. The Constitution seeks to meld these laws, by giving customary law a place in the formal system, but fails to provide mechanisms for resolving a conflict between the two. Such conflict is inevitable having regard to the different values underpinning introduced law and customary law. This difference is exemplified nowhere better than in the gulf between the promotion of women's rights in the Western style charter of rights incorporated in the Constitution and the status of women in Melanesian custom.

In the Tanavulu case, the Court of Appeal gave the following indication of its approach to the exercise of legislative power in a discriminatory fashion:

38 (11 July 1997) unreported, Court of Appeal, Solomon Islands, Civ App 3/1997.

39 Corrin Care, above n 3, 511. 
It is not for this court to comment on the desirability or social implications of such a provision. Parliament has decreed how entitlement is to be established and that is the end of the matter.

The same approach is evident in the Provincial Government Case. Parliament was empowered to legislate for provincial government and in particular to provide for the role of chiefs, and the court was not prepared to interfere with this exercise of power on the grounds of discrimination.

The introductory words to the Constitution, whether correctly referred to as a "preamble" or a "declaration, agreement and pledge", proclaim a commitment to "democratic principles", and "the principles of equality". The recent armed conflict in Solomon Islands demonstrates the fragility of democracy in Solomon Islands. ${ }^{40}$ Its illusory nature is also emphasised by cases such as The Minister for Provincial Government $v$ Guadalcanal Provincial Assembly. ${ }^{41}$ Unless and until the Court is prepared to take a purposive approach to the interpretation of the Constitution and examine legislation with a more critical eye it seems that Parliament may introduce laws that are both undemocratic and discriminatory in their effect without fear that judicial intervention will strike them down. At first instance, Palmer J issued a reminder

40 The issue of greater autonomy for the Provinces, or at least the warring provinces of Guadalcanal and Malaita Provinces, raised its head during the recent armed conflict in Solomon Islands. An agreement was made on 15 October 2000 at Townsville between the Malaita Eagle Force, the Isatabu Freedom Movement, Solomon Islands Government and Malaita Provincial Government and Guadalcanal Provincial Government with a view to terminating the conflict. Part four of the Townsville Agreement addressed the issue under the heading of Political and Socio-Economic issues, in the following terms:

(a) Malaita and Guadalcanal Provinces shall be given more autonomy by devolution or by constitutional amendment to effect self-governing status in order to allow the people of Malaita and Guadalcanal to look after their own affairs and to provide for the needs of their growing populations.

(b) Within twenty-eight days from the date of execution of this Agreement or at a later date as may be agreed to amongst the parties hereto, the Solomon Islands Government shall establish a Constitutional Council to rewrite the Constitution which will provide for more autonomy to provinces, taking into account such recommendations as may be made by the committees currently reviewing the provincial government system and also noting the exclusive powers of Parliament to legislate on such matters.

(c) The Prime Minister shall appoint members of the Constitutional Council after consultation with all provincial governments.

41 The Minister for Provincial Government v Guadalcanal Provincial Assembly (11 July 1997) unreported, Court of Appeal, Solomon Islands, Civ App 3/1997. 
that both Parliament and the courts belong to the people of Solomon Islands. Further research, in order to establish a clear mandate on the place of democracy in the context of the customary society of Solomon Islands, is now well overdue. 
